UNIVERSIDADE DE SÃo PAULO

Faculdade de Odontologia de Ribeirão Preto

SILVIA JORGE DOMICIANO

\title{
Microdureza da Dentina Radicular Adjacente a Materiais RestauRadores Contendo Flúor Após Desafios Erosivos: Estudo in Situ / eX VIVO
}


SiLVIA JORGE DOMICIANO

Microdureza da Dentina Radicular Adjacente a Materiais Restauradores Contendo Flúor Após Desafios ERosivos: Estudo in Situ / EX VIVO

Dissertação apresentada à Faculdade de Odontologia de Ribeirão Preto da Universidade de São Paulo para obtenção do título de mestre em Odontologia Restauradora.

Área de concentração: Dentística

Orientadora: Profa. Dra. Mônica Campos Serra.

Ribeirão Preto

2007 



\section{FolHA DE APROVAÇÃo}

Silvia Jorge Domiciano.

Microdureza da dentina adjacente a materiais restauradores contendo flúor após desafios erosivos: estudo in situl ex vivo.

Dissertação apresentada à Faculdade de

Odontologia de Ribeirão Preto da Universidade de São Paulo para obtenção do título de mestre em Odontologia Restauradora.

Área de concentração: Dentística

Aprovado em: ___ 1_

\section{Banca Examinadora}

Prof. Dr.

Instituição:

Assinatura:

Prof. Dr.

Instituição:

Assinatura:

Prof. Dr.

Instituição: Assinatura: 


\section{DedicatóRIa}

À Deus, por seu infinito amor e grandeza, que me presenteou com a vida.

Aos meus pais, Hélio e Terezinha, por seu amor incondicional, ajudando, amparando e apoiando em todos os momentos, sorrindo a cada sorriso meu e enxugando cada lágrima derramada. Vocês foram e são minha base, possibilitando a realização de todos os meus sonhos, conduzindo meus passos, para trilhar uma vida repleta de conquistas e felicidade. A palavra desistir nunca existiu para mim graças a imensa confiança de vocês em minha capacidade. Obrigada Papai e obrigada Mamãe.

Aos meus irmãos, Eduardo e Camila, por serem o verdadeiro significado dessa palavra, motivo de orgulho e muita felicidade. Amo você.

Aos meus avós Dalvino, Maria José e João, saudades sempre, e Terezinha, que mesmo distante sempre estava presente em pensamento.

Aos meus primos Leandro e Fabiano, aos meus tios, que sempre torceram por mim, apoiaram e acreditaram. A família é a base. 
"Bom é louvar o Senhor, e cantar salmos ao teu nome, ó Altíssimo": anunciar pela manhã a sua misericórdia, e a tua fidelidade durante a noite, com o saltério de dez cordas, e a lira, com cântico ao som da cítara.

Por que me alegras, Senhor, com as tuas obras, e eu exulto com as obras das tuas mãos.

Quão magníficas são, Senhor, as tuas obras! Quão profundos são os teus pensamentos! O homem insensato não conhece, e o néscio não compreende estas coisas. Embora os ímpios floresçam como a erva, e brilhem todos os que fazem mal, estão destinados a eterno extermínio; Mas tu, Senhor, és eternamente excelso. Pois eis que os teus inimigos, Senhor, eis que os teus inimigos perecerão, e serão dispersados todos os que praticam o mal. Exaltastes a minha força como a de um búfalo; ungiste-me com azeite puríssimo.

E os meus olhos olharam com desprezo para meus inimigos, e os meus ouvidos ouviram alegres novas dos malignos que se levantaram contra mim. O justo florescerá como a palma, e como o cedro do Líbano crescerá. Plantados (os justos) na casa do Senhor, florescerão nos átrios do nosso Deus. Darão frutos mesmo na velhice, estarão cheios de seiva e de vigor, Para anunciar quão reto é o Senhor, minha Rocha, e que não há nele iniqüidade “

\section{Salmo 91.}




\section{AGRADECIMENTOS ESPECIAIS}

À Profa. Dra. Mônica Campos Serra, minha orientadora desde meu início na vida científica, por me apresentar este mundo intrigante e interessante da pesquisa. Agradeço toda a paciência, compreensão e confiança em mim valorizando minha capacidade e aceitando minhas limitações.

À mestre e futura Doutora Vivian Colucci, uma amiga maravilhosa, de competência inquestionável, com contribuição fundamental para este trabalho. Vi, obrigada pela amizade, pelo exemplo, incentivo, alegrias, pelas conversas, por deixar eu ser sua madrinha, enfim, por ser uma irmã que eu escolhi para $\operatorname{mim}$.

À Profa. Dra. Cecilia Pedroso Turssi, um exemplo de pesquisadora, com futuro promissor. Obrigada por todo o apoio desde minha iniciação científica até o mestrado. 


\section{AGRADECIMENTOS}

À Faculdade de Odontologia de Ribeirão Preto - USP, na pessoa da senhora diretora, Profa. Dra. Marisa Semprini, pela acolhida durante os cursos de graduação e pós-graduação.

À coordenação do curso de Pós-graduação em Odontologia Restauradora, da Faculdade de Odontologia de Ribeirão Preto - USP, na pessoa do Prof. Dr. Ricardo Gariba Silva.

À Profa. Dra. Regina Guenka Palma Dibb, uma professora extremamente capaz, que me ajudou em momentos de dificuldade, me apoiou e me orientou. Apesar de não termo realizado trabalhos juntas sempre esteve pronta para me ajudar, com carinho e bom humor. Um exemplo de professora.

Às Profas. Dras. Silmara Aparecida Milori Corona, Telma Nunes do Nascimento, Isabel Cristina Fröner e demais professores de Dentística da Faculdade de Odontologia de Ribeirão Preto - USP.

À técnica Patrícia Marchi, pelo seu auxilio durante a parte experimental.

Ao Carlos, secretário da pós-graduação do Departamento de Odontologia Restauradora da Faculdade de Odontologia de Ribeirão Preto - USP, pela sua competência, presteza e amizade, sempre com um sorriso no rosto. 
À Amália e Maria Isabel, secretárias do Departamento de Odontologia Restauradora da Faculdade de Odontologia de Ribeirão Preto - USP.

À Luiza e Rosângela, funcionárias do Departamento de Odontologia Restauradora da Faculdade de Odontologia de Ribeirão Preto - USP.

À Isabel e Regiane, funcionárias da Seção de pós-graduação da Faculdade de Odontologia de Ribeirão Preto - USP.

Aos demais funcionários da FORP - USP, pois cada um à sua maneira, contribuiu para minha formação acadêmica e posterior mestrado.

À Capes, pelo auxílio financeiro.

À Camila Mantoani (Cá), amiga-irmã que ganhei nesses anos em Ribeirão, pessoa incrível, de alegria incomparável, presente em vários momentos, companheira de muitas histórias, inclusive ganhando outra amiga, a Carla.

\begin{abstract}
À Bainca Giacon (Bia), Gabriela Levorato (Gabi), Carol Cioffi e Kátia Arone, um quarteto fantástico que me acolheu e transformou meus dias em Ribeirão muito mais felizes, pessoas lindas que escolhi e tive o prazer de se escolhida para amigas verdadeiras.
\end{abstract}

À Thais e Igor, futuros afilhados que tenho a honra de conviver e sempre me apoiaram. 
Ao Alex Marcon e Rodrigo Perassoli, amigos indispensáveis, pessoas de honestidade e beleza incomparável, são a alegria em pessoa.

Ao Pablinho, amigo que mesmo distante sempre me apoiou e que eu amo muito.

Aos amigos Renato Schiavoni, Leandro Corsi, Fabrício Mundim, Danilo Lattaro, Ingrid Machado, Talitinha Mellara, Maria Elisa Castela, Maria Eduarda (Duda), Lari Freschi, Juzinha Cunha, Má Luccas, Rafael lannotti pessoas maravilhosas que sempre estiveram presente, que agradeço por terem amizade e consideração.

À Cíntia Hirooka, Ju Bissoli, Lu Hirooka, Fabio Scandar e Sinomar Pereira, turma linda que conquistei em Ribeirão, amigos para uma vida toda, sejam nos momentos tristes, sejam nas alegrias e festas.

Ao Gustavo Rocha (Gú) e Diego Caiado, amigos-irmãos que ganhei, companhias perfeitas seja para um churrasco, uma festa, seja para conversas.

Às amigas e colegas de mestrado, Alessandra, Flávia, Michele, Carolina, Dani, companheiras que transformaram o período de mestrado algo muito prazeroso, repleto de risadas, ajudaram a dividir as angústias e dificuldades, deram força, sempre ajudando uma as outras, dentro da FORP ou fora. Amigas eternas. 
Ao Francisco Rehder Neto, aluno de iniciação que agora está no mestrado, que trabalhei junto.

Às colegas de pós-graduação e amigos, Juliana Faraoni, Daniela Chimello, Pedro Turrini, Thaíse Carrasco.

Aos voluntários - Danielle, Renato, Vivian, Flávia, Francisco, Gabriela, Alessandra, Leandro, Fernanda, Bianca, Kátia, Carol e Carolina, pela participação responsável e consciente no projeto, o que garante ao trabalho a confiabilidade necessária.

A todos que, direta ou indiretamente, contribuíram para a conclusão desse trabalho, seja na torcida, com simples palavras, com pensamentos positivos. Obrigada a todos. 
"Quem for fundamentalmente um mestre, apenas toma a sério tudo o que se relaciona com os seus discípulos, incluindo a si próprio."

Friedrich Nietzsche 


\title{
SUMÁRIO
}

\begin{abstract}
Resumo
Abstract

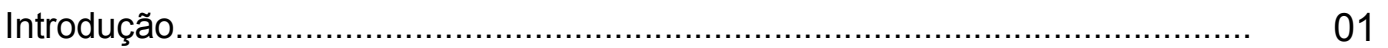

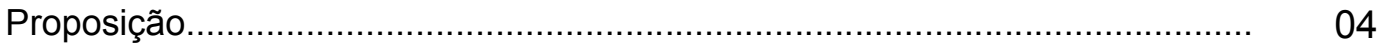

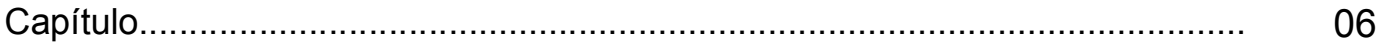

Referências Bibliográficas...................................................................... 27
\end{abstract}

Anexos 


\section{RESUMO}

DOMICIANO, S. J.; COLUCCI, V.; SERRA, M. C. Microdureza da Dentina Radicular Adjacente a Materiais Restauradores Contendo Flúor Após Desafios Erosivos: Estudo in situ lex vivo. 2007. 29p. Dissertação (mestrado) - Faculdade de Odontologia de Ribeirão Preto, Universidade de São Paulo, Ribeirão Preto, 2007.

Este estudo foi realizado a fim de avaliar a microdureza da dentina radicular adjacente a materiais restauradores contendo fluoretos após desafios erosivos. Foi utilizado um delineamento crossover de duas fases de 4 dias consecutivos cada. Cento e doze fragmentos de dentina bovina foram obtidos, nos quais foi confeccionada uma cavidade padronizada no centro de cada um. Estas cavidades foram restauradas aleatoriamente com cimento de ionômero de vidro (Ketac-fil) ou resina composta (Filtek Z-250). Em seguida, os fragmentos restaurados foram distribuídos aleatoriamente entre os 14 voluntários, montados em aparelhos, cada um com 4 espécimes restaurados com o mesmo material. A partir do segundo dia, metade do aparelho, com dois espécimes, foi imersa em refrigerante de limão por $90 \mathrm{~s}$, quatro vezes por dia, fora da boca por 3 dias. Após um intervalo de 3 dias, fragmentos restaurados com o material ainda não utilizado foram montados no aparelho e foi iniciada a segunda fase do experimento. Após os desafios erosivos, foram realizadas as medidas da microdureza da dentina adjacente às restaurações. Independente do material empregado, os espécimes erodidos apresentaram menores valores de microdureza $(p<0.0001)$. Com relação aos materiais restauradores, foi verificado que a dentina, nas condições deste estudo, apresentou maiores valores de microdureza quando restaurada com cimento de ionômero de vidro $(p<0.0001)$. Sendo assim, podemos concluir que o cimento de ionômero de vidro diminui a progressão da erosão da dentina radicular adjacente à restauração.

Palavras-chave: erosão, dentina, material restaurador, flúor. 


\begin{abstract}
DOMICIANO, S. J.; COLUCCI, V.; SERRA, M. C. Effect of different restorative materials on root dentine erosion: an in situ/ex-vivo study. 2007. 29p. Dissertation (master's degree) - School of Dentistry of Ribeirão Preto, University of São Paulo, Ribeirão Preto, 2007.

This study sought to evaluate the microhardness of root dentine adjacent to fluoride-containing restorative materials after erosive challenge. A cross-over study was performed in two phases of 4 consecutive days each. One hundred and twelve bovine root dentine slabs were obtained, and standardized box-shaped cavities were prepared at center of each specimen. The prepared cavities were randomly restored with glass-ionomer cement or composite resin. The slabs were randomly assigned among 14 volunteers, which wore intraoral palatal device containing 4 restored root dentin slabs. Starting on the second day, half of the palatal acrylic devices were immersed extraorally in a lemonade-like carbonated soft drink for 90 seconds, four times daily for 3 days. After 3-day wash-out, dentine slabs restored with the alternative material were placed into palatal appliance and the volunteers started the second phase of this study. After erosive challenges, microhardness measurements were performed. Regardless of the restorative material employed, eroded specimens demonstrated lower microhardness value $(p<0.0001)$. At any given dentine condition examined in this study, dentine restored with glass-ionomer cement showed higher microhardness values $(p<0.0001)$. It may be concluded that the glass-ionomer cement decreases the progression of root dentine erosion at restoration margin.
\end{abstract}

Key words: erosion, dentine, restorative materials, fluoride. 
- 


\section{INTRODUÇÃO}


Modelos de pesquisa in situ têm sido utilizados para avaliar as propriedades cariostáticas de materiais fluoretados (Ten Cate, J. M, 1994). Este tipo de experimento é considerado um estágio intermediário entre estudos in vivo e in vitro (Classen, A.B.S, Ǿgaard, B, 1999) e é útil nas pesquisas sobre erosão (Hunter, M. L. et al, 2003). Esse tipo de desgaste dental tem etiopatogenia relacionada à desmineralização dental (Lussi, A et al, 1995; Lussi, A et al, 2004), proporcionada pela ação de ácidos de origem intrínseca ou extrínseca na superfície dental sem biofilme (Ganss, C, 2006). De origem extrínseca, o consumo freqüente de ácidos de origem alimentar, como os refrigerantes (Hooper, S. M. et al, 2007), está associado à presença e progressão do desgaste erosivo (Lussi, A, 2006). Diversas estratégias têm sido descritas visando à redução do desgaste erosivo. Dentro desse contexto, a principal recomendação é reduzir a exposição a ácidos (Hughes, J. A et al, 2004; Lussi, A. et al, 2004, Lussi, A et al, 2006), através da diminuição da freqüência de ingestão e tempo de contato com a estrutura dental (Hughes, J. A et al, 2004; Lussi, A. et al, 2004). Entretanto, há casos em que a perda significativa de tecido dental, a hipersensibilidade e o envolvimento estético, requerem a instituição de medidas terapêuticas restauradoras, para devolver a forma e a saúde (Lambrechts, P. et al, 1996; Levitch, L.C et al, 1994).

As alterações no conteúdo mineral provocadas pela exposição a bebidas ácidas podem interferir na dureza do tecido dentinário. Medidas de microdureza superficial permitem a detecção de estágios iniciais de enfraquecimento da dentina desmineralizada (Attin, T, 2006). A utilização de material fluoretado na restauração de lesões de erosão também poderia influenciar esta dinâmica, dependendo da concentração deste íon. Dentre os materiais utilizados destacam-se os cimentos de ionômero de vidro convencionais e, as resinas compostas. Em relação à progressão de lesões de cárie, há evidências laboratoriais de que os cimentos de ionômero de vidro previnem e/ou controlam a formação destas lesões em esmalte na cavidade e também a uma distância da restauração (Hara, A. T, 2002). Entretanto, o efeito desse 
material na dentina radicular, frente a desafios erosivos, em ambiente bucal, ainda não foi verificado.

Sendo assim, este estudo avaliou a microdureza da dentina radicular adjacente ao material restaurador contendo fluoretos quando submetidos a desafios ácidos, através de um modelo in situ. 
Proposição

$\overline{ }$ 
Essa dissertação tem como objetivo apresentar um artigo científico para avaliar a influência de material restaurador com flúor na microdureza superficial da dentina radicular bovina adjacente a restaurações quando submetidos a desafios erosivos, in situl ex vivo. 
Capítulo

$=$ 


\section{Effect of different restorative materials on root dentine erosion}

Domiciano SJ; Colucci V; Serra MC

Silvia Jorge Domiciano, Department of Restorative Dentistry, School of Dentistry of Ribeirão Preto, University of São Paulo, Ribeirão Preto, SP, Brazil

Vivian Colucci, Department of Restorative Dentistry, School of Dentistry of Ribeirão Preto, University of São Paulo, Ribeirão Preto, SP, Brazil

Mônica Campos Serra, Department of Restorative Dentistry, School of Dentistry of Ribeirão Preto, University of São Paulo, Ribeirão Preto, SP, Brazil

${ }^{*}$ Corresponding author

Mônica Campos Serra

Faculdade de Odontologia de Ribeirão Preto - USP

Departamento de Odontologia Restauradora

Av. do Café, S/N Monte Alegre CEP: 14040-904 Ribeirão Preto-SP, Brazil

Phone: +55 1636024075

e-mail: mcserra@forp.usp.br 


\section{Abstract}

This study sought to evaluate the microhardness of root dentine adjacent to fluoride-containing restorative materials after erosive challenge. A cross-over study was performed in two phases of 4 consecutive days each. One hundred and twelve bovine root dentine slabs were obtained, and standardized boxshaped cavities were prepared at center of each specimen. The prepared cavities were randomly restored with glass-ionomer cement or composite resin. The slabs were randomly assigned among 14 volunteers, which wore intraoral palatal device containing 4 restored root dentin slabs. Starting on the second day, half of the palatal acrylic devices were immersed extraorally in a lemonade-like carbonated soft drink for 90 seconds, four times daily for 3 days. After 3-day wash-out, dentine slabs restored with the alternative material were placed into palatal appliance and the volunteers started the second phase of this study. After erosive challenges, microhardness measurements were performed. Regardless of the restorative material employed, eroded specimens demonstrated lower microhardness value $(p<0.0001)$. At any given dentine condition examined in this study, dentine restored with glass-ionomer cement showed higher microhardness values $(p<0.0001)$. It may be concluded that the glass-ionomer cement decreases the progression of root dentine erosion at restoration margin.

Key words: erosion, dentine, restorative materials, fluoride 


\section{Introduction}

Since $19^{\text {th }}$ century, the incidence and prevalence of dental erosion have been increasingly being reported, mainly in adult patients. ${ }^{1}$ Due to a chemical process, the contact of the dental surface with non-bacterial acids ${ }^{2,3}$ promotes irreversible loss of dental tissue that leads to the formation of non-carious lesions, such as dental erosion. This pathology can be caused by intrinsic agents, such as recurrent vomiting or regurgitation of the gastric content ${ }^{4,5}$ or extrinsic factors, including the ingestion of acid drinks, foods or medication, ${ }^{6,7,8}$ with the former being the major cause of the erosion. ${ }^{9}$

An accurate diagnosis becomes essential for an effective control of dental erosion. For extrinsic acids, the goal is to reduce acid exposure by decreasing the frequency of ingestion of potentially harmful drinks and foodstuffs as well as minimizing contact time. ${ }^{10}$ However, owing to the restricted contribution of the patients in modifying their dietary habits, the damages caused by acid challenge can reach a certain degree, in which the aesthetic appearance is unacceptable ${ }^{11}$ and dentine is hypersensitive ${ }^{12}$ and thus, an oral rehabilitation becomes necessary. ${ }^{13}$

The restorative treatments should be as conservative as possible. ${ }^{14}$ As result of the improvements in mechanical properties of filling materials and in adhesive techniques, ${ }^{13,15}$ it has been possible to rehabilitate eroded dentition in a less-invasive manner. ${ }^{13}$ The use of fluoride-releasing restorative materials, such as the glass-ionomer cement, has been associated with a cariostatic effect on root dentine subjected to cariogenic challenges, $16,17,18$ by decreasing demineralization and enhancing remineralization process. ${ }^{19}$ 
In vitro and in situ studies have demonstrated that establishment of fluoridation measurements significantly reduce the erosion progression in enamel and dentine. ${ }^{20,21}$ Additionally, it has been shown that the use of slowrelease devices for fluoride delivery may facilitate rapid remineralization enamel and dentine submitted to acid challenges. ${ }^{22}$ However, there are no studies that evaluate the effect of fluoride from glass-ionomer cement restorations on progression of root dentine erosion.

Considering the limitations in literature, the current study sought to evaluate in situ the effect of fluoride-containing materials on progression of root dentine erosion.

\section{Materials and methods}

\section{Experimental Design}

A cross-over and double-blind study was conducted in two phases of four days each, with a 3-day wash-out period interposed at the cross-over point (Figure 1). Initially, the protocol for this study was reviewed and approved by the Ethics Committee of the School of Dentistry of Ribeirão Preto (USP). Fourteen adult volunteers were selected and they received verbal and written information concerning the study and gave signed and witnessed consent to participate.

The factors involved in this study were restorative material in two levels:

Group A, glass-ionomer cement (Ketac Fil, 3M Dental Products, St Paul, MN, USA); and Group B, composite resin - control (Filtek Z250, 3M Dental Products, St Paul, MN, USA); and dentine condition in two levels (I - eroded and II uneroded). The experimental sample, comprised of 112 specimens of dentine, 
was randomly assigned in replicate to the 14 volunteers, which were considered as statistical blocks. The response variable was microhardness measurements performed in dentine around the restorations.

\section{Specimen preparation and selection of slabs}

Bovine incisors, freshly extracted, with age standardized at four years, were cleaned with scaler and water/pumice slurry in dental prophylactic cups and they were stored in a $0.1 \%$ thymol solution at $4^{\circ} \mathrm{C}$. Teeth were sectioned with a water-cooled diamond saw in a sectioning machine (Isomet 1000; Buehler, Lake Bluff, IL, USA) to obtain two fragment from the cervical third ( $3 \mathrm{x}$ $3 \times 2 \mathrm{~mm}$ ), totaling 150 samples. The dentine surfaces were flattened and ground in a water-cooled polishing machine (Politriz DP-9U2, Struers A/S, Copenhagen, DK-2610, Denmark) with 400-, 600- and 1200- grades of $\mathrm{Al}_{2} \mathrm{O}_{3}$ papers, and polished on cloths with a $0.3 \mu \mathrm{m}$ alumina suspension (Buehler, Lake Bluff, IL, USA). ${ }^{23}$ Slabs were immersed in deionized water and sonicated for $10 \mathrm{~min}$ to clear the surface. Afterwards, specimens were sterilized with ethylene oxide, ${ }^{23}$ carefully inspected for surface defects, and were kept in $100 \%$ humidity environmental at $4^{\circ} \mathrm{C}$.

Slabs were pretested for Knoop microhardness, in order to standardize

the test pieces. ${ }^{23}$ A total of 112 out of 150 slabs were selected based on the average SMH data.

\section{Cavity preparation and restoration of root dentine blocks}

Box-shaped cavities ( $2 \times 2 \times 1 \mathrm{~mm}$ ) were prepared with \#2096 diamond burs (KG Soresen, Barueri, SP, Brazil) at the center of each slab, with a highspeed handpiece (Dabi-Atlante, Ribeirão Preto, SP, Brazil). The high-speed handpiece was fixed in a milling machine (MPC, EIQuip, São Carlos, SP, 
Brazil), in which axles movement were monitored by digital comparing clocks, supplying precision of $0.01 \mathrm{~mm}$ in the cavities dimension. New burs were replaced after every five preparations.

After cavity preparation, blocks were randomly assigned to be restored with one of the materials to be tested: Z250 (control) or Ketac Fil. The restorative procedures were performed according to manufacturer's instructions. For Z250, surfaces were treated with a 35\% phosphoric acid gel (Scotchbond gel, 3M Dental Products, St Paul, MN, USA) for 15 seconds, rinsed for the same time and gently dried to keep a moist surface. Then, an etch and rinse adhesive system (Single Bond 2 Adper, 3M Dental Products, St Paul, MN, USA) was applied for 15 seconds; the remaining solvent was evaporated with a brief, gentle dry air jet and light-cured for 10 seconds. After that, a hybrid composite resin restoration was built on the cavity. The composite restoration was cured for 20 seconds, with a visible light-curing unit (XL 3000, 3M/ESPE, USA) with a $450-\mathrm{mW} / \mathrm{cm}^{2}$ output. The restorative material inserted in the cavities was pressed for 1 minute with a glass-plate under a load of $500 \mathrm{~g}$. For glass-ionomer cement restorations were allowed to cure for $7 \mathrm{~min}$. Cavities restored with Ketac Fil were protected using non-colored nail varnish. After 24 hours in relative humidity at $37^{\circ} \mathrm{C}$, the specimens were polished in a watercooled polishing machine with $600-$ and 1200 - grades of $\mathrm{Al}_{2} \mathrm{O}_{3}$ papers and they were kept in $100 \%$ humidity environmental at $37^{\circ} \mathrm{C}$.

\section{Palatal appliance mounting}

For each volunteer, one removable intraoral appliance was constructed in acrylic resin, with four sites $(3 \times 3 \times 3 \mathrm{~mm})$, being two in each side of the midline. Four dentine blocks restored with the same material were randomly 
mounted into sites, with the restored surface recessed approximately $1.0 \mathrm{~mm}$ below the surface of the appliance to avoid tongue friction. ${ }^{23}$ At the beginning and end of each experimental day, appliances with the contained specimens, were soaked in a $0.2 \%$ chlorhexidine mouthwash for $2 \mathrm{~min}$. Overnight the appliances were placed in sealed containers on moist cotton wool. ${ }^{24}$

\section{Clinical phase}

Before starting the intraoral procedures, a three-day lead-in period was established. The volunteers were instructed to keep habitual methods of brushing teeth and to use exclusively the toothbrush and dentifrice supplied to them by the researchers. All volunteers employed a fluoride-containing dentifrice over the experiment and they were guided to suspend the use of fluoridation measurements, such as mouthrinses. After the lead-in period, the volunteers wore intraoral palatal device containing 4 restored root dentine slabs. On the first day, no erosive procedures were carried out to allow salivary pellicle formation. Starting on the second day, half of the palatal acrylic devices, with 2 root dentine slabs were immersed extraorally in a lemonade-like carbonated soft drink for $90 \mathrm{~s}$, four times daily, for 3 days. During period of intraoral procedures, the volunteers had brushed only the inner part of their appliances with the same toothbrush and dentifrice employed to oral hygiene. At the end of the first intraoral phase, a 3-day wash-out period was founded, where the volunteers have not used the intraoral device. After the wash-out period, another 4 dentine slabs, restored with the alternative material, were placed into palatal appliance and the volunteers started the second phase of this study.

To avoid a possible carry-across effect, ${ }^{25}$ in the first period, seven volunteers wore palatal appliance with dentine blocks restored with composite 
resin and the other seven subjects inserted palatal devices loaded with dentine slabs restored with glass-ionomer cement. In the second period, volunteers were then crossed over to the alternative restorative material, ${ }^{26}$ characterizing a $2 \times 2$ cross-over design (Figure 1).

\section{Microhardness measurements around restorations}

At the end of each intraoral phase, the specimens were positioned on acrylic rods with paralelometer and the measurements around the restorations were realized in a microhardness (HMV-2) testing with a Knoop diamond and a 25-gram static load which was applied for 10 s. The surface microhardness measurements on root dentine were performed $300 \mu \mathrm{m}$ from the margin of the restored cavities.

\section{$\underline{\text { Statistical methods }}$}

Results were analyzed by applying the ANOVA according to the split-plot model, after checking normality and homocedasticity. The differences among mean values were compared by using Tukey's test at significance level of $5 \%$. The carry-over and period effects were evaluated by independent $t$ test. The statistical analysis was performed with Statgraphics Centurion XV.

\section{Results}

The effects of carry-over were not statistically significant $(p=0.255)$ in contrast with period effects which were statistically significant $(p=0.009)$. Microhardness data were analyzed by split-plot ANOVA, which showed interaction between the main factors: dentine eroded / dentine uneroded and restorative material (glass-ionomer cement and composite resin) $(p<0.0001)$. The mean values and standard deviations for microhardness of the root dentine 
eroded or uneroded restored with different restorative materials are summarized in Table I. Regardless of the restorative material employed, eroded specimens demonstrated lower microhardness values $(p<0.0001)$. Within restorative materials, it was observed that, at any given dentine condition examined in this study, dentine restored with glass-ionomer cement showed higher microhardness values $(p<0.0001)$.

\section{Discussion}

Glass-ionomer cements are composed of fluoride-containing silicate glass and polyalkenoic acids which are set by an acid-based reaction between the components. During the setting reaction, a variety of ionic constituents is released from the glass, including fluoride. ${ }^{27}$ Fluoride has been documented as a protector agent of the erosion progression in enamel and dentine $20,21,28,29$ however, the action of fluoride-containing restorative materials on development of root dentine erosion has not been evaluated yet. This study was delineated to evaluate the possible protective effect of fluoride from glass-ionomer cement in controlling the root dentine erosive lesions.

Microhardness measurements to evaluate differences between restorative materials were performed at $300 \mu \mathrm{m}$ from the margin of the restored cavities. The choice of the distance was based in previous studies that evaluate the extent of the cariostatic effect on root dentine provided by fluoridecontaining materials ${ }^{30}$ and the fluoride penetration from conventional glassionomer cements into dentine. ${ }^{31}$ It was demonstrated that dentin microhardness values adjacent to Ketac fil were higher than the Z250 (control group) up to distance of $300 \mu \mathrm{m}$ for cariogenic challenges ${ }^{30}$ and the incorporation of fluoride into dentine occurs at $300 \mu \mathrm{m}$ around restoration. ${ }^{31}$ 
The results of the current study showed that glass-ionomer cement was able to interfere with root dentine erosion progression, without completely preventing its development. The continual presence of a low concentration of fluoride appears to inhibit demineralization and enhance remineralization on eroded surface, as occurs for cariogenic challenges. ${ }^{30,32,33}$

Even tough all volunteers have used fluoride-containing dentifrice during the experimental phase, the protective effect for root dentine erosion was shown only for specimens restored with glass ionomer cement. A possible explanation for this is the fact that the restored dentine was inserted in the mouth of the volunteers four days after the restorative procedures. Several studies revealed that the major fluoride release usually occurs within the first seven days. 34,35 Thus, the fluoride effects might be amplified by the experimental conditions ${ }^{30}$ since the erosive challenges were realized within this period. Thus, it is doubtful that glass-ionomer cements can have a significant erosive preventive effect over a longer period, because the amount of fluoride ions released from these materials decreases with the aging of the material. ${ }^{36}$

Previous studies evaluated the cariostatic effect of aging restorations and they demonstrated that freshly mixed glass ionomers significantly prevented enamel softening ${ }^{37}$ however, the protective effect against demineralization disappeared with time. ${ }^{26,37}$ In other way, the disappearing fluoride effect could be reestablished by subsequent fluoride application. ${ }^{37}$

Daily exposition of filling materials to fluoridated dentifrices has demonstrated a high rechargibility for glass-ionomers, while the replenishment of resin based materials seems to be negligibly small. ${ }^{27}$ Fluoride-releasing materials may act as a fluoride reservoir and may increase the fluoride level in 
saliva, biofilm and dental hard tissues. ${ }^{27}$ Probably, the glass ionomer cement would be capable to incorporate the fluoride from dentifrice and to maintain it for a long time in the oral cavity, favoring the remineralizing effect of the saliva and intervening which the acid challenges.

The saliva has been considered the most important biological factor influencing dental erosion due to its ability to act, directly on the erosive agent itself by diluting, clearing, neutralizing and buffering acids, play a role in forming a protective membrane, and to reduce the demineralization rate and enhance remineralization to eroded enamel and dentine. ${ }^{38}$ However, saliva collected in vitro may undergo a number of changes which reduce its protective effect against acid degradation of tooth tissue, what highlights the important role of in situ models, particularly when dentine is tested. ${ }^{39}$ Additionally, the temperature influences dentine erosion, ${ }^{40}$ and all these factors were the main reasons for the use of an in situ study.

Similar study designs have been previously employed to evaluate the effect of fluoride on tooth erosion. For convenience, bovine dentine has been widely used in dental research as a substitute for human teeth. ${ }^{28}$ Morphological differences exist between substrates, which results in higher rates of demineralization for bovine teeth, although the differences are only quantitative and not qualitative. ${ }^{41}$ An enhancement in the lesion formation rate was also expected because polished surfaces were used, and they are more susceptible to acid challenges than natural surface. ${ }^{42}$ However, polished surfaces are recommended to produce well-defined indentations in the surface microhardness test. ${ }^{43}$ 
The experimental protocol employed was based on previous intraoral investigations, 23, 44, 45, 46, 47 with slight modifications. The volunteers intakes were performed four times daily, since four or more nutritional acid intakes per day are associated with higher risk of development and progression of erosion. 48, 49

Calcium, phosphate, $\mathrm{pH}$ value and to a lesser extent fluoride content of a drink are important factors explaining erosive attacks. Sprite Diet $(\mathrm{pH} 2.84$ with $\mathrm{CO}_{2}$; citric acid, $18.4 \mathrm{~g} / 100 \mathrm{ml}$; fluoride) was chosen as the demineralization solution because of its proven erosive capacity. ${ }^{46,50}$ Although samples had been extraorally demineralized, to avoid mineral loss from the volunteer's teeth, the detrimental influence of Sprite Diet was clearly demonstrated by the significantly lower SMH observed for the eroded groups.

Despite the statistical differences between periods, as shown in the ttest, the microhardness values adjacent to glass-ionomer cement were higher than that observed around composite resin restoration. Thus, the difference in periods may be ascribed to the volunteers hygiene habits and - or volunteers motivation, ${ }^{24}$ but it did not affect the results of the current study.

Although both clinical and experimental observations show that individual wear mechanisms rarely act alone but interact with each other, ${ }^{51}$ the abrasion by toothbrush was not performed on dentine restored slabs, since the response variable could be harmed and the possible effect of fluoride-containing restorative materials could be masked, as occurs in a previous study. ${ }^{52}$ Future researches, with another variable response, could highlight the combined effect of erosion and abrasion on root dentine erosion formed in situ. 
It is important to note that, in vivo, the pattern of the effect of fluoridecontaining restorative materials on root dentine erosion is the result of a complex reaction among different chemicals, being dependent on many factors that could not be replicated in a in situ/ex-vivo study. Thus, supplementary research is required to investigate the influence of fluoride uptake of restorative materials, as well as the effect of the aging process of restorative material on root dentine erosion, close to clinical conditions.

\section{Acknowledgments}

The authors are grateful to Cecília Pedroso Turssi, postdoctoral research associate from the Department of Restorative Dentistry, for her precious advice, experimental design and statistical analysis. Acknowledgements are also due to CAPES and FAPESP (process 2005/01680-9; 04/07613-9), which have supported this study. This manuscript is a part of a dissertation submitted by the first author to the school of Dentistry of Ribeirão Preto, USP, for the Masters of Science degree in Restorative Dentistry. 


\section{References}

1. Amaechi BT, Higham SM. Dental erosion: possible approaches to prevention and control. J Dent, 2005; 33: 243-252.

2. Eccles JD. Tooth surface loss from abrasion, attrition and erosion. Dental Update $1994 ; 35: 373-381$.

3. Imfeld T. Dental erosion. Definition, classification and links. Eur J Oral Sci 1996; 104: 151-155.

4. Jarvinen V, Rytomaa I, Heinonen OP. Risk factors in dental erosion. Journal of Dental Research 1991; 70:942-947.

5. Scheutzel P. Etiology of dental erosion-intrinsic factors. Eur J Oral Sci 1996; 104:178-90.

6. Eccles JD, Jenkins WG. Dental erosion and diet. Journal of Dentistry $1974 ; 2: 153-159$.

7. Asher C, Read MJF. Early enamel erosion in children associated with the excessive consumption of citric acid. British Dental Journal 1987;162:384-387.

8. Zero DT. Etiology of dental erosion-extrinsic factors. European Journal of Oral Sciences 1996; 104:162-177.

9. Barbour ME, Rees JS. The laboratory assessment of enamel erosion: a review. J Dent 2004; 32: 591-602.

10. Lussi A, Jaeggi T, Zero D. The role of diet in the aetiology of dental erosion. Caries Res 2004; 38: 34-44.

11. Tay FR, Pashley DH. Resin bonding to cervical sclerotic dentin: a review. J Dent 2004; 32: 173-196. 
12. Lambrechts $P$, Van Meerbeek B, Perdigao J, Gladys S, Braem M, Vanherle G. Restorative therapy for erosive lesions. Eur J Oral Sci 1996; 104: $229-240$.

13. Jaeggi T, Grüninger A, Lussi A. Restorative therapy of erosion. Monogr Oral Sci 2006; 20: 200-214.

14. Yip $\mathrm{KH}$, Smales RJ, Kaidonis JA. The diagnosis and control of extrinsic acid erosion of tooth substance. Quintessence Int 2002; 33: 516-520.

15. Xie D, Brantley WA, Culbertson BM, Wang G. Mechanical properties and microstructures of glass-ionomer cements. Dental Mater 2000; 16: 129138.

16. Tam LE, Chan GP, Yim D. In Vitro caries inhibition effects by conventional and resin-modified glass-ionomer restorations. Oper Dent 1997; 22: 4-14.

17. Dionysopoulos $\mathrm{P}$, Kotsanos N, Papadogiannis $\mathrm{Y}$, Konstantinidis A. Artificial secondary caries around two new F-containing restoratives. Oper Dent 1998; 23: 81-86.

18. Pereira PN, Inokoshi S, Tagami J. In vitro secondary caries inhibition around fluoride releasing materials. J Dent 1998; 26: 505-510.

19. Mukai $\mathrm{Y}$, ten Cate. Remineralization of advanced root dentin lesions in vitro. Caries Res 2002; 36: 275-280. 
20. Ganss C, Klimek J, Schaffer U, Spall T. Effectiveness of two fluoridation measures on erosion progression in human enamel and dentine in vitro. Caries Res 2001; 35: 325-330.

21. Ganss C, Klimek J, Brune V, Schurmann A. Effects of two fluoridation measures on erosion progression in human enamel and dentine. Caries Res 2004; 38: 561-566.

22. Toumba KJ, Curzon ME. Slow-releasing devices for fluoride delivery to high-risk individuals. Caries Res 2001; 35: 10-13.

23. Messias DCF, Serra MC, Turssi CP. Potential effect of sodium bicarbonate-containing dentifrice in controlling enamel erosion in situ. Am J Dent 2007; in press.

24. Hooper SM, Newcombe RG, Faller R, Eversole S, Addy M, West NX. The protective effects of toothpaste against erosion by orange juice: studies in situ and in vitro. J Dent 2007; 35: 476-481.

25. Hujoel PP, DeRouen TA. Validity issues in split-mouth trials. J Clin Periodontol 1992; 19: 625-627.

26. Hara AT, Turssi CP, Ando M, González-Cabezas C, Zero DT, Rodrigues Jr AL, Serra MC, Cury JA. Influence of fluoride-releasing restorative material on root dentine secondary caries in situ. Caries Res 2006; 40: 435-439.

27. Wiegand A, Buchalla W, Attin T. Review on fluoride-releasing restorative materials - Fluoride release and uptake characteristics, antibacterial 
activity and influence on caries formation. Dental Mater 2006; 23: 343362.

28. Vieira A, Lugtenborg M, Ruben JL, Huysmans MCDNJM. Brushing abrasion of eroded bovine enamel pretreated with topical fluorides. Caries Res 2006; 40: 224-230.

29. Lagerweiji MD, Buchalla W, Kohnke S, Becker K, Lennon AM. Prevention of erosion and abrasion by a high fluoride concentration gel applied at high frequencies. Caries Res 2006; 40: 148-153.

30. Hara AT, Turssi CP, Serra MC, Nogueira MC. Extent of the cariostatic effect on root dentin provided by fluoride-containing restorative materials. Oper Dent 2002; 27: 480-487.

31. Tarn LE, Chan GP, Yim D. In vitro caries inhibition effects by conventional and resin modified glass-ionomer restorations. Oper Dent 1997; 22: 4-14.

32. Serra MC, Cury JA. The in vitro effect of glass-ionomer cement restoration on enamel subjected to a demineralization and remineralization model. Quintessence Int 1992; 2: 143-147.

33. Benelli EM, Serra MC, Rodrigues Jr AL, Cury JA. In situ anticariogenic potential of glass-ionomer cement. Caries Res 1993; 27: 280-284.

34. Hsu C-YS, Donly KJ, Drake DR, Wefel JS. Effects of aged fluoridecontaining restorative materials on recurrent root caries. J Dent Res 1998; 77: 418-425.

35. Vermeersch G, Leloup G, Vreven J. Fluoride release from glass-ionomer cements. J Oral Rehabil 2001; 28: 26-32. 
36. Creanor SL, Carruthers LM, Saunders WP, Strang R, Foye RH. Fluoride uptake and release characteristics of glass ionomer cements. Caries Res 1994; 28: 322-328.

37. Seppa L. Fluoride release and effect on enamel softening by fluoridetreated and fluoride-untreated glass ionomer specimens. Caries Res 1994; 28: 406-408.

38. Hara AT, Lussi A, Zero DT. Biological factors. Monogr Oral Sci 2006; 20 : 88-99.

39. Hall AF, Buchnan CA, Millett DT, Creanor SL, Strang R, Foye RH. The effect of saliva on enamel and dentine erosion. J Dent 1999; 27: 333339.

40. West NX, Hughes JA, Addy M. Erosion of dentine and enamel in vitro by dietary acids: the effect of temperature, acid character, concentration and exposure time. J Oral Rehabil 2000; 27: 875-880.

41. Mellberg JR: Hard-tissue substrates for evaluation of cariogenic and anticariogenic activity in situ. J Dent Res 1992; 71:913-919.

42. Ganss C, Klimek J, Schwarz N. A comparative profilometric in vitro study of the susceptibility of polished and natural human and dentine surfaces to erosive demineralization. Arch Oral Biol 2000; 45: 897-902.

43. Attin T. Methods for assessment of dental erosion. Monogr Oral Sci 2006; 20: 152-172.

44. Hara AT, Turssi CP, Teixeira ECN, Serra MC, Cury JA. Abrasive wear on eroded root dentine after different periods of exposure to saliva in situ. Eur J Oral Sci 2003; 111: 423-427. 
45. Attin T, Knöfel S, Buchalla W, Tütüncü R. In situ evaluation of different remineralization periods to decrease brushing abrasion of demineralized enamel. Caries Res 2001b; 35: 216-222.

46. Attin T, Siegel S, Buchalla W, Lennon AM, Hanning C, Becker K. Brushing abrasion of softened and remineralised dentin: an in situ study. Caries Res 2004; 38: 62-66.

47. Turssi CP, Faraoni JJ, Rodrigues Jr AL, Serra MC. Na in situ investigation into the abrasion of eroded dental hard tissues by a whitening dentifrice. Caries Res 2004; 38: 473-477.

48. Lussi A, Schaffner M. Progression of and risk factors for dental erosion and wedge-shaped defects over a 6-year period. Caries Res 2000; 34 : $182-187$.

49. O'Sullivan EA, Curzon MEJ. A comparison of acidic dietary factors in children with and without dental erosion. J Dental Child 2000; 67: 186192.

50. Attin T, Zirkel C, Hellwig E. Brushing abrasion of eroded dentin after application of sodium fluoride solutions. Caries Res 1998; 32: 344-350.

51. Addy M, Shellis RP. Interaction between attrition, abrasion and erosion in tooth wear. Monogr Oral Sci 2006; 20: 17-31.

52. Turssi CP, Hara AT, Domiciano SJ, Serra MC. Study on the potential inhibition of root dentine wear adjacent to fluoride-containing restorations. J Mater Sci Mater Med DOI: 10.1007/s10856-007-3140-4. 
Table 1. Means of microhardness values $(\mathrm{KHN})$ and standard deviations of eroded and uneroded root dentine according to restorative material employed

\begin{tabular}{ccc}
\hline & Uneroded & Eroded \\
\hline Ketac fil & $52,7(3.9) \mathrm{Aa}$ & $50.5(7.6) \mathrm{Ab}$ \\
\hline $\mathbf{Z 2 5 0}$ & $53,0(4.7) \mathrm{Aa}$ & $40.7(4.3) \mathrm{Bb}$ \\
& \\
\hline & \\
Capital letters - comparison within columns \\
Lower case - comparison within lines \\
Same letter indicates statistical similarity
\end{tabular}

\begin{tabular}{|c|c|c|c|c|}
\hline & $\begin{array}{l}\text { Lead-in } \\
3 \text { days }\end{array}$ & $\begin{array}{c}\text { Phase } 1 \\
4 \text { days }\end{array}$ & $\begin{array}{c}\text { Wash-out } \\
3 \text { days }\end{array}$ & $\begin{array}{c}\text { Phase } 2 \\
4 \text { days }\end{array}$ \\
\hline $\begin{array}{l}\text { Dentine } \\
\text { restored with } \\
\text { Ketac fil }\end{array}$ & & $\begin{array}{c}\text { Volunteers } \\
1-7\end{array}$ & & $\begin{array}{l}\text { Volunteers } \\
\quad 8-14\end{array}$ \\
\hline $\begin{array}{l}\text { Dentine } \\
\text { restored with } \\
\mathrm{Z250}\end{array}$ & & $\begin{array}{c}\text { Volunteers } \\
8-14\end{array}$ & & $\begin{array}{c}\text { Volunteers } \\
1-7\end{array}$ \\
\hline
\end{tabular}

Figure 1. Experimental design

(Adapted from Hara et al., 2006) 
REFERÊNCIAS BIBLIOGRÁFICAS

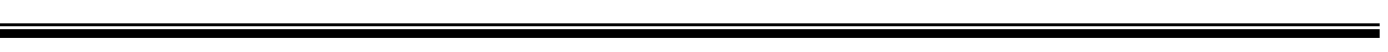




\section{REFERÊNCIAS BIBLIOGRÁFICAS":}

1. ATTIN T. Methods for assessment of dental erosion. In: LUSSI A. Dental Erosion. Monogr. Oral Sci. Basel, Karger, v.20, p.152-162, 2006;

2. CLASEN, A.B.S, ǾGAARD, B. Experimental intra-oral caries models in fluoride research. Acta Odontol.Scand., v.57, p.334-341, 1999;

3. GANSS C. Definition of erosion and links to tooth wear. In: LUSSI A. Dental Erosion. Monogr. Oral Sci. Basel, Karger, v.20, p.9-16, 2006;

4. HARA A.T., TURSSI C.P., SERRA M.C., NOGUEIRA M.C.S. Extent of the cariostatic effect on root dentin provided by fluoride-containing restorative materials. Operative Dentistry, v.27, p.480-487, 2002

5. HUGHES J.A., WEST N.X., ADDY M. The protective effect of fluoride treatments aganist enamel erosion in vitro. J Oral Rehab, v.31, p. 357-363, 2004;

6. HUNTER, M.L., HUGHES, J.A., PARKER, D.M., WEST, N.X., NEWCOMBE, R.G., ADDY, M. Development of low erosive carbonated fruit drinks. 1. Evaluation of two experimental orange drinks in vitro and in situ. Journal of Dentistry, v.31, p. 253-260, 2003;

7. HOOPER S.M., NEWCOMBE R.G., FALLER R., EVERSOLE S., ADDY M., WEST N.X. The protective effects of toothpaste against erosion by orange juice: studies in situ and in vitro. J Dent, v.35(6), p.476-81, 2007;

8. LAMBRECHTS P., VAN MEERBEEK B., PERDIGÃO J., GLADYS S., BRAEM M., VANHERLE G. Restorative therapy for erosive lesions. European Journal of Oral Sciences, v.104, p.229-240, 1996;

9. LEVITCH L.C., BADER J.D., SHUGARS D.A., HEYMANN H.O. Non-carious cervical lesions. Journal of Dentistry, v.22, p.195-207, 1994;

\footnotetext{
^ De acordo com as normas da Associação Brasileira de Normas Técnicas (ABNT) - NBR 6023.
} 
10. LUSSI A., HELLWING E., ZERO D., JAEGGI T. Erosive tooth wear: diagnosis, risk factors and prevention. Am J Dent, v.19(6), p.319-25, 2006;

11. LUSSI A. Erosive tooth wear - a mutlifactorial condition of growing concernan increasing knowledge. In: LUSSI A. Dental Erosion. Monogr. Oral Sci. Basel, Karger, v.20, p.1-8, 2006;

12. LUSSI A., JAEGGI T., JAEGGI-SCHÄRER S. Prediction of the erosive potential of some beverages. Caries Res, v.29, p.349-354, 1995;

13. LUSSI A., JAEGGI T., ZERO D. The role of diet in the aetiology of dental erosion. Caries Res, v.38, p.34-44, 2004;

14. TEN CATE, J. M., In situ models, physico- chemical aspects. Advances in Dental Research, v.8, p.125-133, 1994. 
Anexos

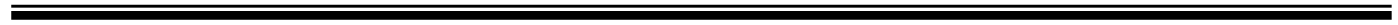




\section{ANEXOS}

$24-\mathrm{Nov}-2007$

Manuscript number: JBMR-A-07-0969

Dear Dr. Colucci:

We are pleased to receive your manuscript entitled Effect of different restorative materials on root dentine erosion by Domiciano, Silvia; Colucci, Vivian; Serra, M.C.. We will be sending it out for review shortly.

To track the progress of your manuscript through the editorial process using our new web-based system, simply point your browser to:

http://mc.manuscriptcentral.com/jbmr-a

and log in using the following user ID and password:

(User ID) : vicolucci@yahoo.com.br

(Password): If you do not remember your password, please click on this link to set a new password http://mc.manuscriptcentral.com/jbmra?URL_MASK=9TZTyf 4 JHSrHyMjSHqk4

If you should have any specific deadlines directly related to this manuscript, please let us know as soon as possible.

Please remember in any future correspondence regarding this article to always include its manuscript ID number JBMR-A-07-0969.

If you experience problems associated with the submission web site, please contact the Scholarone support staff directly using the Get Help Now link in the top right corner of the website.

Many thanks for submitting your manuscript.

Sincerely, Lisa Brodsky Assistant Managing Editor

Journal of Biomedical Materials Research 


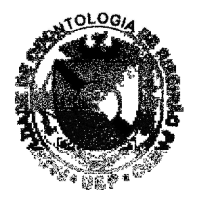

\section{UNIVERSIDADE DE SAOO PAULO FACULDADX DE ODONTOLOCLA DE RIRERA O PRETO COMTEE DE TTC AM TESOULA \\ Aronta of Caft, $/ \mathrm{R}^{\circ}$. Telefone: (016) $3602-3983$ \\ 140 a d

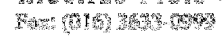

OF.CEP/405/FORP/27102006

Prezado(a) Pesquisador(a),

Ref.: Processo n. 2006.1.1048.58.6 Cranen.00560.136.000-06

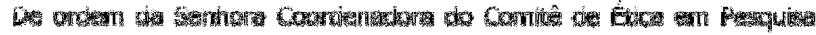

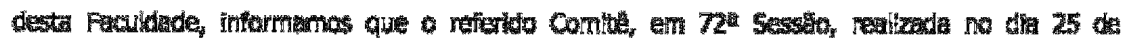
outubro de 2006, deliberou aprovar o Projeto de Pesquisa envolvendo seres humanos intitulado: "Microdureza da dentina radicular adjacente a materiais restauradores contendo flúor após desafios erosivos: Estudo in situ", a ser desenvolvido por Vossa Senhoria na Faculdade

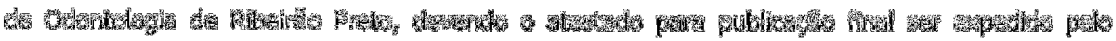

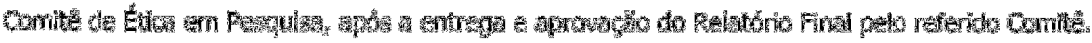

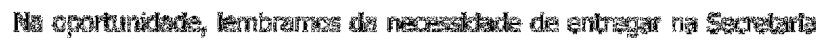
do Comitê, o Relatório Final até o dia 30 de abril de 2007 , con o formulário preenchido pelo pesquisador responsável conforme modelo que se encontra no site da FORP/USP (link. Comissões Comitê de Exica an Pesquisa - Formilários do Pesquisador para entrega dos Relattrios Parcial au Finosily.

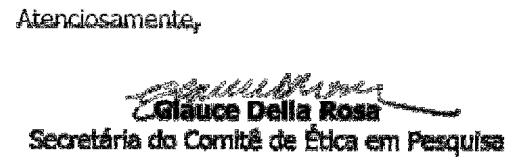

Ilma. Sra.

P.G. SILVTA JORGE DOMTCTANO

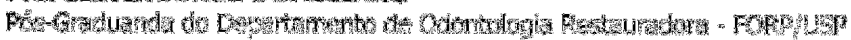

GDR/bgep

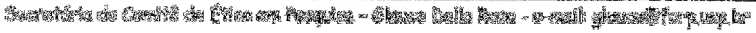




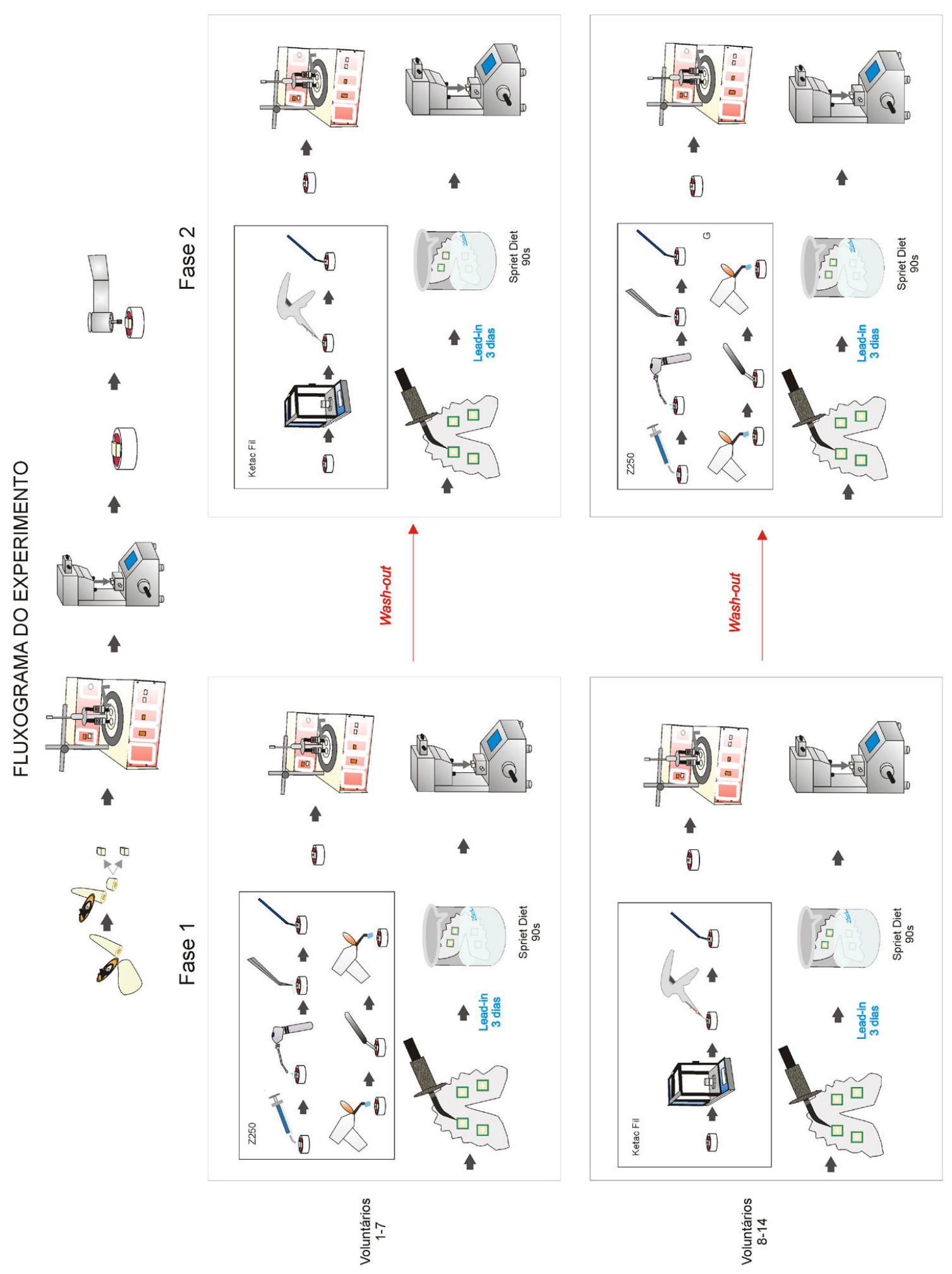

